\title{
Soluble malate dehydrogenase of Geophagus brasiliensis (Cichlidae, Perciformes): Isolated isoforms and kinetics properties
}

\author{
Maria Regina de Aquino-Silva ${ }^{1}$, Maria Luiza Barcellos Schwantes ${ }^{2}$, Flavia Simone Munin², \\ Arno Rudi Schwantes ${ }^{2}$ and Silvana Pereira dos Santos ${ }^{1}$ \\ ${ }^{1}$ Universidade do Vale do Paraiba, Instituto de Pesquisa \& Desenvolvimento, \\ São José dos Campos, SP, Brazil. \\ ${ }^{2}$ Departamento de Genética e Evolução, Universidade Federal de São Carlos, São Carlos, SP, Brazil.
}

\begin{abstract}
Kinetic properties and thermal stabilities of Geophagus brasiliensis skeletal muscle unfractionated malate dehydrogenase (MDH, EC 1.1.1.37) and its isolated isoforms were analyzed to examine a possible $s M D H-B^{*}$ locus duplication in a fixation process influenced by genetic drift. Two optimal $\mathrm{pHs}$ were detected: 7.5 for $\mathrm{AB} 1$ unfractionated muscle phenotype and its $B 1$ isoform, and 8.0 for AB1B2 unfractionated muscle phenotype, $A$ and $B 2$ isoforms. While $G$. brasiliensis $A$ isoform could be characterized as thermostable, the duplicated $B$ isoform cannot be assumed as thermolabile. $K_{\mathrm{m}}$ values for isolated B2 isoforms were 1.6 times lower than for B1. A duplication event in progress best explains the electrophoretic six-band pattern detected in $G$. brasiliensis, which would be caused by genetic drift.
\end{abstract}

Key words: gene duplication, $\mathrm{sMDH}$, substrate concentration, temperature, $\mathrm{pH}$ isoforms.

Received: August 23, 2006; Accepted: July 10, 2007.

\section{Introduction}

The malate dehydrogenase system (MDH, EC 1.1.1.37; Malate: NAD oxidoreductase) is represented by two major forms in vertebrates and invertebrates: soluble (sMDH) and mitochondrial (mMDH). The two forms differ in their electrophoretic mobility (Markert and Moller, 1959), kinetic behaviour (Banaszak and Bradshaw, 1975), amino acid composition (McAlister-Henn, 1988), antigenic properties (Kitto and Lewis, 1967) and are controlled by separated gene loci (Davidson and Cortner, 1967; Bailey et al., 1969, 1970; Whitt, 1970). Two gene loci, $s M D H-A^{*}$ and $S M D H-B^{*}$, encode sMDH in most studied fish and amphibian species (Schwantes and Schwantes, 1977, 1982 a,b; De Luca et al., 1983; Coppes et al., 1987; FenerichVerani et al., 1990; Monteiro et al., 1991, 1998; Farias and Almeida-Val, 1992; Lin and Somero, 1995a,b; Caraciolo et al., 1996, Aquino-Silva et al., 1997; 1998; 2003, Lin et al., 2002)

The subtropical teleost Geophagus brasiliensis (Perciformes), studied by Monteiro et al. (1991, 1998), showed a six-banded pattern for sMDH in $84 \%$ of the specimens. To explain this pattern three hypotheses have been

Send correspondence to Maria Regina de Aquino-Silva. Instituto de Pesquisa \& Desenvolvimento, Universidade do Vale do Paraíba, Avenida Shishima Hifumi 2911, 12010-400 São José dos Campos, SP, Brazil. E-mail: mreginaquino@yahoo.com.br. suggested, (i) a duplication event in processing their $s M D H-B^{*}$ locus, (ii) the presence of three loci $s M D H-A^{*}$, $s M D H-B 1^{*}$; and $s M D H-B 2^{*}$ with a null allele within $B 2^{*}$, and (iii) overdominance of a variant allele $* 119$ at $s M D H-B^{*}$. In a previous paper, Aquino-Silva et al. (1998) analyzed the effect of temperature and $\mathrm{pH}$ on unfractionated sMDH liver, muscle and heart of Geophagus in order to examine their Km (OAA), tissue specificities by Klebes method and thermostability tests. These tests have resulted in similar responses for both B-isoforms, in both sMDH phenotypes, suggesting a recent locus duplication for $s M D H-B^{*}$. To verify this hypothesis, the present paper describes optimum $\mathrm{pH}$, thermal stability, and $\mathrm{Km}(\mathrm{OAA})$ of total Geophagus sMDH and isolated isoforms.

\section{Material and Methods}

\section{Tissue preparation}

Using a net, forty-one specimens of G. brasiliensis were collected from the Monjolinho Reservoir at the Federal University of São Carlos, State of São Paulo, Brazil. Annual temperature at the G. brasiliensis capture site ranges from $12.3{ }^{\circ} \mathrm{C}-23.0^{\circ} \mathrm{C}$. White muscle from each individual was dissected immediately after being captured and kept at $-20^{\circ} \mathrm{C}$. A small piece of each tissue was homogenized (w/v) in a $50 \mathrm{mM}$ phosphate buffer, $\mathrm{pH} 7.0$ using a Potter-Elvejhem tissue homogenizer and then centrifuged 
at $19,000 \mathrm{x} \mathrm{g}$ for $30 \mathrm{~min}$ at $4{ }^{\circ} \mathrm{C}$ in a Sorvall RC5B centrifuge. Crude extract were used for electrophoretic and spectrophotometric analyses.

\section{Enzyme electrophoesis}

Electrophoreses were carried out in horizontal gels containing $14 \%(\mathrm{w} / \mathrm{v})$ corn starch prepared according to Val et al. (1981), using the pH 6.9 buffer system described by Whitt (1970). A voltage gradient of $5 \mathrm{~V} / \mathrm{cm}$ was applied for $14-17 \mathrm{~h}$ at $4{ }^{\circ} \mathrm{C}$. After electrophoresis, the starch gels were sliced lengthwise and the lower halves incubated in an MDH staining solution described by Monteiro et al. (1991). Nomenclature of sMDH gene loci, subunits and iso/allozymes was determined according to Shaklee et al. (1989). lsolation of sMDH isoforms was carried out by using an electrophoretic technique according to De Luca et al. (1983).

\section{Determination of $\mathrm{pH}$ and temperature optima}

For $\mathrm{pH}$-activity relation studies, a $50 \mathrm{mM}$ sodium phosphate buffer ( $\mathrm{pH} 5.0-8.5)$ and a $0.2 \mathrm{mM}$ Tris-HCI buffer ( $\mathrm{pH} 9.0-9.5$ ) was used and assays were carried out in a solution containing $0.33 \mathrm{mM}$ oxaloacetate and $0.20 \mathrm{mM}$ NADH. Crude extracts and isolated isoforms were tested for thermal stability by submitting each sample to $50{ }^{\circ} \mathrm{C}$ for 10-60 min in the absence of substrate or coenzyme. Subsequently the samples were cooled on ice and centrifuged at $19.000 \mathrm{~g}$ for $30 \mathrm{~min}$ at $4{ }^{\circ} \mathrm{C}$. Their residual activities were examined at $25{ }^{\circ} \mathrm{C}$ in the direction of oxaloacetate reduction through the change in absorbance at $340 \mathrm{~nm}$ in a HP-8452A Diode Array Spectrophotometer using a temperature controlled cuvette holder. The assays were carried out in a $50 \mathrm{mM}$ imidazole chloride buffer containing $0.33 \mathrm{mM}$ oxaloacetate and $0.20 \mathrm{mM} \mathrm{NADH}$. Controls were kept in an ice-water mixture.

\section{Kinetic analysis}

The kinetic parameters of sMDH (total and isolated isoforms) were determined at $20{ }^{\circ} \mathrm{C}$ by measuring the oxidation of NADH spectrophotometrically at $340 \mathrm{~nm}$. The assays were carried out in a $50 \mathrm{mM}$ imidazole chloride buffer containing $0.20 \mathrm{mM} \mathrm{NADH}$ and different concentrations of oxaloacetate. Oxamate at $10 \mathrm{mM}$ was added to inhibit lactate dehydrogenase activity resulting from any pyruvate occurring in the assay medium. All assays were performed in triplicate and initiated by adding $10 \mu \mathrm{L}$ of enzyme (crude extract) or $100 \mu \mathrm{L}$ (isolated isoform) to $1.0 \mathrm{~mL}$ of assay medium. Apparent Michaelis-Menten constants $(\mathrm{Km})$ were calculated by Lineweaver Burk method using doublereciprocal plots of velocity $v s$. substrate concentrations.

\section{Statistical analysis}

Allele frequencies were determined by Chi-square tests and analyzed for Hardy-Weinberg equilibrium. Statistical differences among optimum $\mathrm{pH}$, thermal stability, and $\mathrm{Km}$ (OAA) values of total and isolated isoforms of
Geophagus sMDH were determined by Student's T test with $95 \%$ confidence interval.

\section{Results}

Muscle extracts from 41 G. brasiliensis specimens confirmed both electrophoretic patterns for sMDH obtained previously by Monteiro et al. $(1991,1998)$ and Aquino-Silva et al. (1998) (Figure 1). Assuming HardyWeinberg equilibrium, the $\chi^{2}$ value for allele frequencies $(178.6 ; 1$ d.f. $\mathrm{p}<0.001)$, indicates that these samples are not in equilibrium for this locus. A homogeneity $\chi^{2}$ test $(0.197$ 1d.f. $0.75>\mathrm{p}>0.5$ ) showed that the phenotypic proportion between the two samples (Aquino-Silva et al., 1998 and present sample) were maintained.

Comparisons of Geophagus skeletal muscle unfractionated sMDH and its isolated isoforms have shown similar $\mathrm{pH}$ optima for oxaloacetate reduction: $\mathrm{AB} 1, \mathrm{~A}$ and $\mathrm{B} 1$ $\mathrm{pH} 7.5$; $\mathrm{AB} 1 \mathrm{~B} 2, \mathrm{~B} 1$ and $\mathrm{B} 2 \mathrm{pH} 8.0$ (Figure $2 \mathrm{~A}$ and $\mathrm{B}$ respectively). Statistical analyses of optimum $\mathrm{pH}$ values showed no significant difference between muscle extract $\mathrm{AB} 1 \mathrm{~B} 2$ and its isoforms $(\mathrm{p}=0.26$ for $\mathrm{AB} 1 \mathrm{~B} 2 v s . \mathrm{B} 1$; $\mathrm{p}=0.60$ for $\mathrm{AB} 1 \mathrm{~B} 2 v s$. $\mathrm{B} 2$ and $\mathrm{p}=0.60$ for $\mathrm{B} 1 v s . \mathrm{B} 2$ ).

Thermal stability of unfractionated sMDH from skeletal muscle extracts is shown in Figure 3A. The half-lives of $\mathrm{AB} 1$ and $\mathrm{AB} 1 \mathrm{~B} 2$ muscle extracts were about 54 and 5 min respectively and the differences were significant $(\mathrm{p}=0.01)$. To determine more precisely the thermal stability of the $\mathrm{A}, \mathrm{B} 1$ and $\mathrm{B} 2$ isoforms, partially purified isoforms

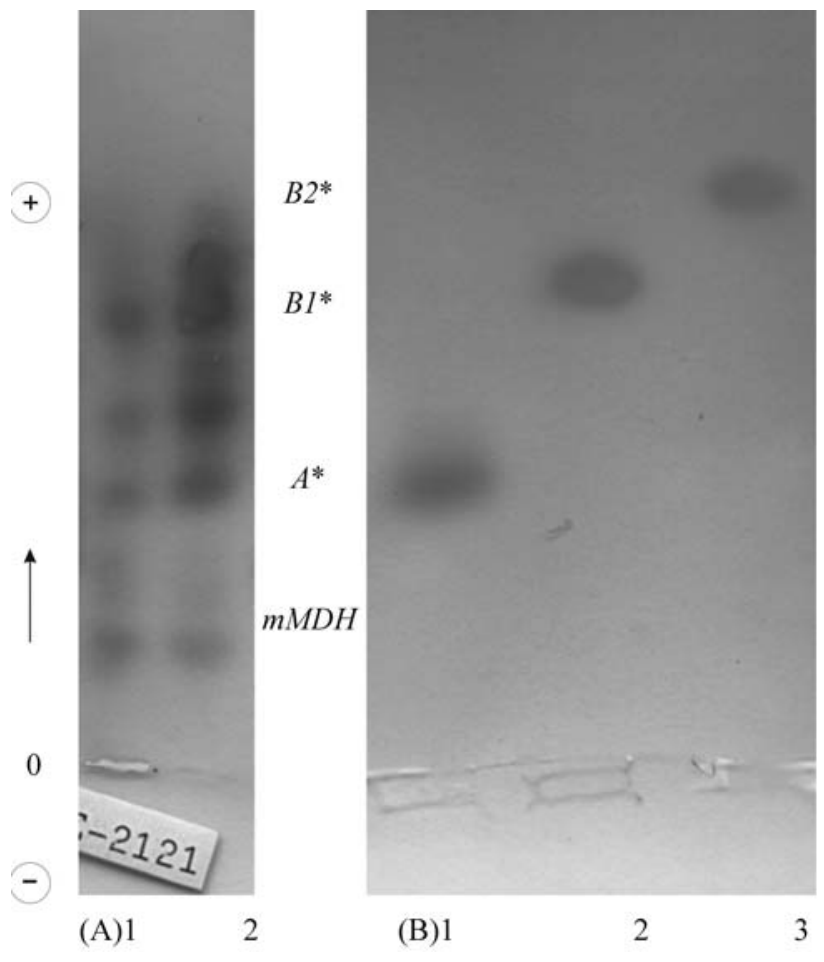

Figure 1 - (A) Malate dehydrogenase from skeletal muscle extracts of Geophagus brasiliensis: (1) $A B 1^{*}$ (2) $A B 1 B 2 *$ (B) sMDH isolated isoforms: (1) A, (2) B1 and (3) B2. mMDH mitochondrial form; $\mathrm{O}$ - origin. 

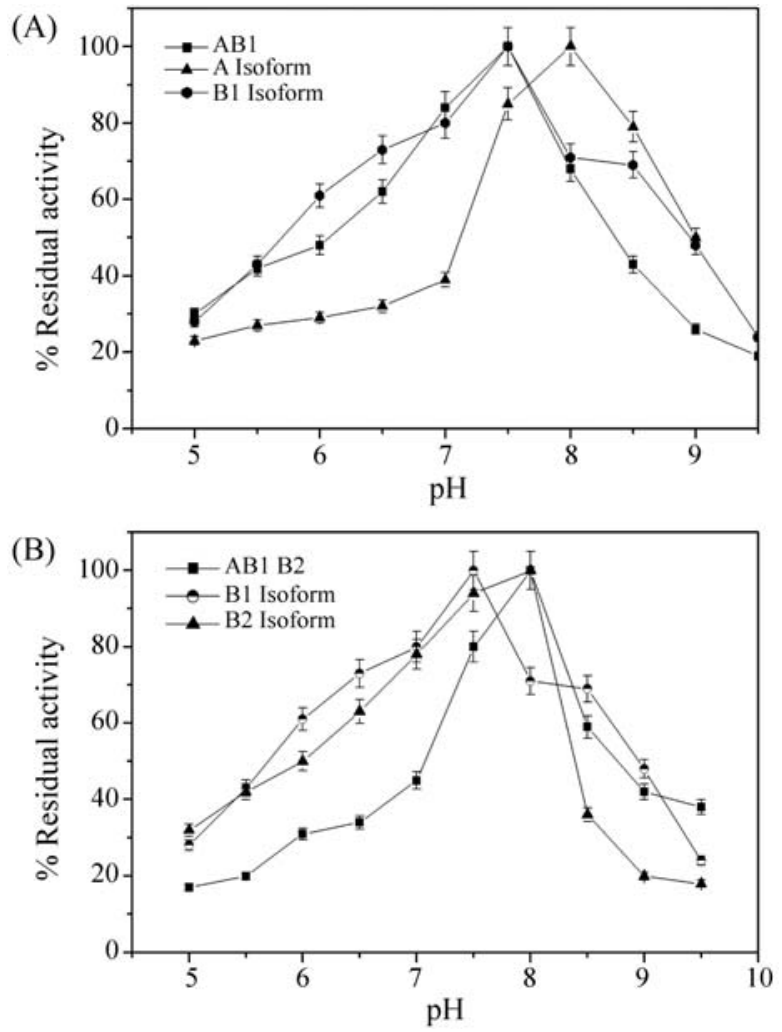

Figure 2 - (A) Optimal $\mathrm{pH}$ of sMDH from skeletal muscle of G. brasiliensis $\mathrm{AB} 1$ phenotype and its isoforms. (B) optimal $\mathrm{pH}$ of $\mathrm{sMDH}$ from skeletal muscle of G. brasiliensis AB1B2 phenotype and its isoforms. Error bars are $95 \%$ confidence intervals for each $\mathrm{pH}$ determination.

were also submitted to thermostability tests (Figure 3B). The half-lives of $\mathrm{A}, \mathrm{B} 1$ and $\mathrm{B} 2$ isoforms were about $60 \mathrm{~min}$ for $\mathrm{A}$ and $5 \mathrm{~min}$ for $\mathrm{B} 2$. The $\mathrm{B} 1$ isoform did not show half-life during the tests., but no significant differences were observed among all the half-life values ( $p=0.47$ for $\mathrm{A} 2 v s . \mathrm{B} 1 ; \mathrm{p}=0.97$ for $\mathrm{A} 2 v s . \mathrm{B} 2 ; \mathrm{p}=0.76$ for $\mathrm{B} 1 v s . \mathrm{B} 2)$.

The responses of both crude extract phenotypes and their respective predominant isoforms to increasing oxaloacetate concentrations are shown in Figure 4 (A and B). Optimal substrate concentrations differed between isoforms ( $\mathrm{A}$ and $\mathrm{B} 1=0.03 \mathrm{mM} \mathrm{L}^{-1}$ and $\mathrm{B} 2=0.02 \mathrm{mM} \mathrm{L}^{-1}$ ) but not between crude extracts $\left(\mathrm{AB} 1\right.$ and $\left.\mathrm{AB} 1 \mathrm{~B} 2=0.03 \mathrm{mM} \mathrm{L}^{-1}\right)$. The $\mathrm{Km}(\mathrm{OAA})$ value (Figure 5) obtained for $\mathrm{B} 1$ isolated isoform was 1.6 times higher than that of the $\mathrm{B} 2$ isoform $\left(0.024 \mathrm{mM} \mathrm{L}^{-1} \times 0.015 \mathrm{mM} \mathrm{L}^{-1}\right)$. Statistical analyses revealed significant differences when $\mathrm{AB} 1$ vs. $\mathrm{B} 1$ isoform $(\mathrm{p}=0.001)$ and $\mathrm{AB} 1 \mathrm{~B} 2$ vs. B2 isoform $(\mathrm{p}=0.078)$ were compared.

\section{Discussion}

A pair of duplicated genes may represent two kinds of homology: orthology or paralogy. Duplicated genes related by speciation are orthologous and genes related by regional events or duplication of a single gene, e.g. through ploidy changes are paralogous (Ferris and Whitt, 1977, 1978,
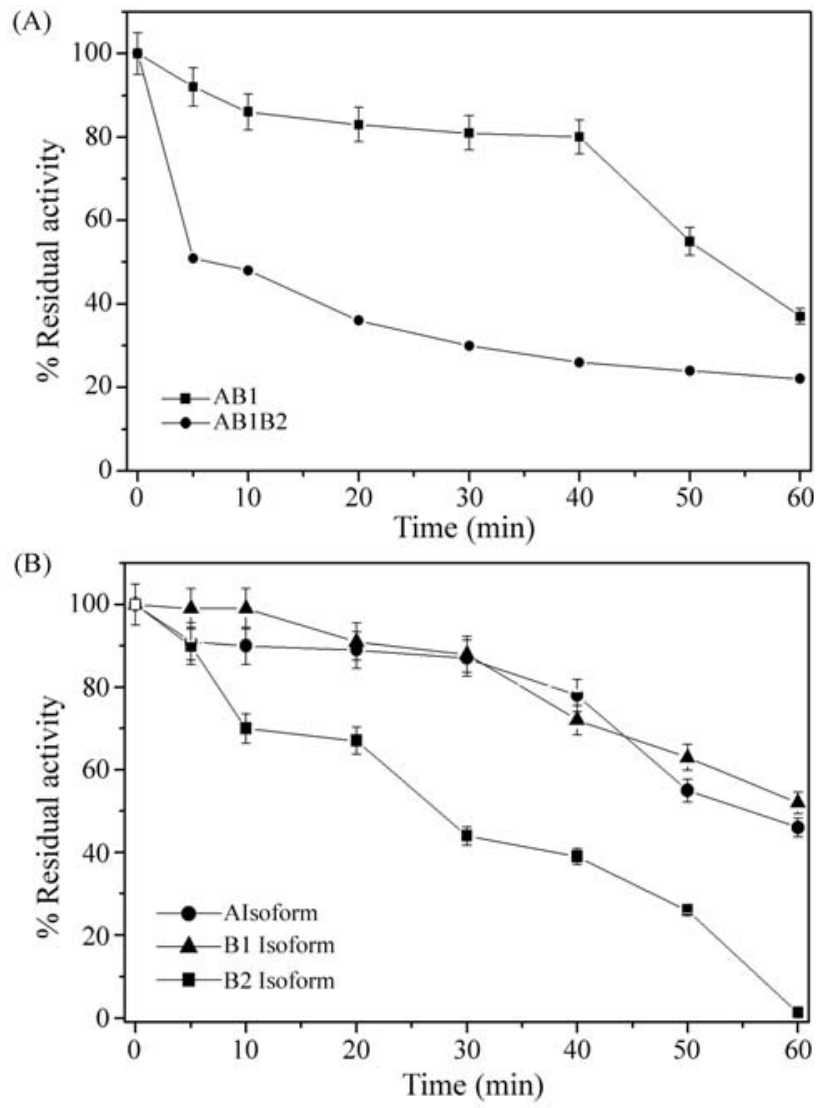

Figure 3 - (A) Thermal inactivation of MDH from $\mathrm{AB} 1$ and AB1B2 phenotype of G.brasiliensis. (B) Thermal inactivation of sMDH from A, B1 and B2 isoforms. Error bars are $95 \%$ confidence intervals for each temperature determination.

1979; Ferris, 1984). The homologies of duplicated genes can be inferred from measurements of $\mathrm{pH}$ optima, heat stability and other kinetic properties like optimum substrate concentration or $K \mathrm{~m}$ values.

In general, specific activity, thermostability and other kinetic enzyme properties vary with $\mathrm{pH}$ fluctuation. De Luca et al. (1983), studying adaptative features of sMDH in the subtropical fish Astyanax fasciatus showed that its isoforms have different $\mathrm{pH}$ optima for oxaloacetate reduction. In contrast, in comparative studies of sMDH paralogs of four species of Pacific barracudas adapted to different temperatures, Lin and Somero (1995b) obtained similar optima $\mathrm{pH}$ (7.6 and 7.7) for both isoforms in the direction of oxaloacetate reduction,. For Geophagus the optimum $\mathrm{pH}$ obtained with muscle extracts for the AB1 phenotype and $\mathrm{B} 1$ isoform ( $\mathrm{pH} 7.5)$, was significantly different from the one obtained for $\mathrm{AB} 1 \mathrm{~B} 2$ phenotype, $\mathrm{A}$ and $\mathrm{B} 2$ isoforms ( $\mathrm{pH} 8.0)$.

Differences in thermostability properties between paralogous isoforms were not detected in G. brasiliensis, which is completely different from results described for some other fish where $S M D H-A^{*}$ encodes a thermostable and $s M D H-B^{*}$ a thermolabile isoform (Schwantes and 

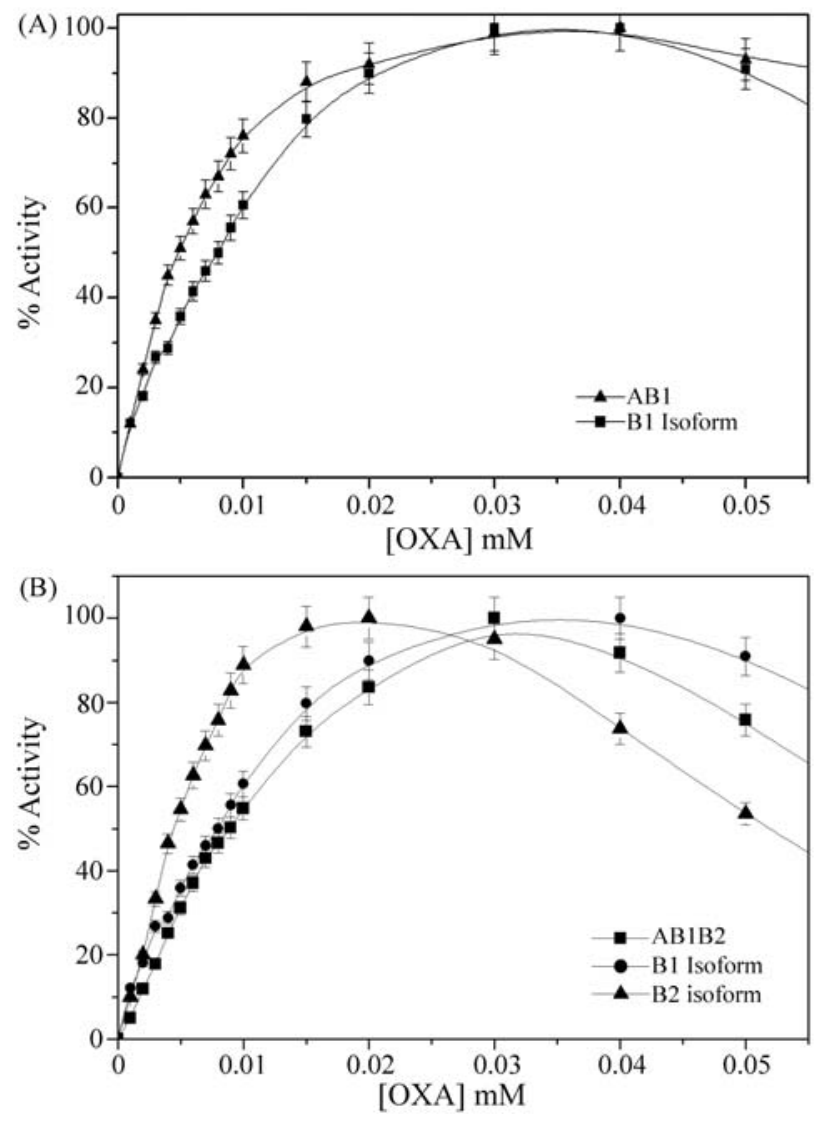

Figure 4 - (A) MDH saturation curves (oxaloacetate reduction) from $G$. brasiliensis $\mathrm{AB} 1$ phenotype and $\mathrm{B} 1$ isoform (B) $\mathrm{MDH}$ saturation curves (oxaloacetate reduction) from G. brasiliensis AB1B2 phenotype and its isoforms (B1 and B2). Error bars are 95\% confidence intervals for each determination.

Schwantes, 1982a,b; De Luca et al., 1983; Coppes et al., 1987; Farias and Almeida-Val, 1992; Lin and Somero, 1995a,b; Caraciolo et al., 1996; Lin et al.,2002; AquinoSilva et al., 1998).

Comparative studies on thermostable and thermolabile sMDH isoforms of barracudas from different physiological temperature ranges revealed similar kinetic properties for orthologs and varying ones for paralogs (Lin and Somero, 1995a,b). According to these authors, the absence of a thermolabile isoform in equatorial barracuda (Sphyraena ensis) could occur through two mechanisms, gene loss (or loss of a functional form of the gene) encoding this isoform, or repression of gene transcription at high temperatures. Thus, if the thermolabile isoform is not required physiologically, the gene that encodes this isoform may effectively be lost. However, Farias and Almeida-Val (1992) and Caraciolo et al. (1996) studying sMDH of Amazon fishes, detected a thermolabile locus product. Farias and Almeida-Val (1992) also showed a recent duplication of $s M D H-B^{*}$ in Amazon cichlids. Schwantes and Schwantes (1982a), studying the adaptative features of sMDH loci in a temperate estuarine fish Leiostomus xanthurus (habitat temperature range $5-30{ }^{\circ} \mathrm{C}$ ), showed that

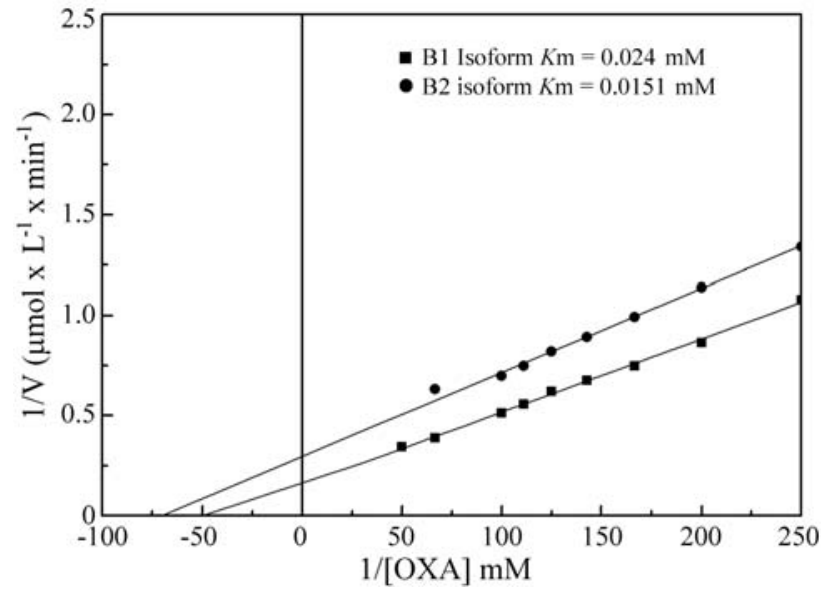

Figure 5 - Km curves for sMDH B1 and B2 isoforms,of $G$. brasiliensis; $\mathrm{r}=0.999$ and 0.998 respectively.

A and B subunits occur in different tissues at different levels, possibly reflecting environmental temperature fluctuations. On the other hand, Lin and Somero (1995a,b) studying the eurythermal species Gillichthys mirabilis (habitat temperature range $9-38{ }^{\circ} \mathrm{C}$ ), showed that the two sMDH's isoforms vary in ratio seasonally and as a result of acclimation. According to these authors, the findings suggest that temperature can affect one or more of the processes that establish sMDH isozyme ratios, such gene transcription or protein degradation.

Thermostability tests realized with AB1 muscle extract, the tissue in which Klebes tests showed the presence of two A subunits for one of B1 (Aquino-Silva et al. 1998), showed an enzyme half-life at 54 min of incubation. However, when the isolated A and B1 isoforms were incubated, their half-lives were $60 \mathrm{~min}$ for the $\mathrm{A}$ isoform, whereas the $\mathrm{B} 1$ isoform did not show half-life during the tests. When themostability tests with AB1B2 muscle extract were performed, the tissue in which Klebes tests showed the presence of eight A subunits for one of B1 and one of B2 (Aquino-Silva et al., 1998) the half-life was obtained within $5 \mathrm{~min}$. The isolated A and B1 isoforms showed similar results obtained for the $\mathrm{AB} 1$ phenotype, and the isolated B2 isoform showed half-life within $30 \mathrm{~min}$. According to Lin and Somero (1995b), some characteristics are conserved among orthologs of each sMDH isoform. Comparisons of orthologs with respect to themostability have shown that while the A isoform of Geophagus could be characterized as a thermostable isoform (like in $L$. xanthurus determined by Schwantes and Schwantes, 1982 a,b), in A. fasciatus determined by De Luca et al., 1983, and in S. idiates by Lin et al, 2002), the possibly duplicated B isoform could not be characterized as thermolabile.

$K \mathrm{~m}$ value conservation is interpreted as reflecting selection for the retention of the catalytic and regulatory capacities of enzymes and it is manifest through adaptations to changes in pressure, osmotic conditions, $\mathrm{pH}$, as well as 
temperature (Hochacka and Somero, 1984). In the present paper, $K \mathrm{~m}$ (OAA) values obtained for the A isolated isoform were 2.5 times higher than for $\mathrm{B} 1$ and 4.0 times higher than for the $\mathrm{B} 2$ isoform $(0.06 \mathrm{mM} \times 0.024 \mathrm{mM} \times$ $0.015 \mathrm{mM}$ ). The values obtained for the isolated $\mathrm{B} 1$ and $\mathrm{B} 2$ isoforms were 1.6 higher for $\mathrm{B} 1$ than for $\mathrm{B} 2$ the isoform $(0.024 \mathrm{mM} \times 0.015 \mathrm{mM})$.

$\mathrm{Km}(\mathrm{OAA})$ values for $\mathrm{B} 1$ and $\mathrm{B} 2$ are comparable to other species. Consequently, the presence of a null allele proposed by Monteiro et al. $(1991,1998)$ is not probable. Considering the hypothesis of overdominance proposed by the same authors, the coefficient of selection and the segregational load ( 0.73 and 0.42 , respectively according to Aquino-Silva et al. 1998) obtained for this allele also makes this hypotesis improbable. In addition to this, allele frequencies indicated that these samples are not in equilibrium for this locus.

Three different biological functions have been proposed for sMDH: gluconeogenesis, lipogenesis and malate-aspartate shuttle during aerobic glucolysis. Since these processes occur differently in various tissues, this would explain the different activities of the multiple forms of MDH. Their presence or absence would be due to different physiological and metabolic roles. According to Coppes et al. (1987), white muscle malate is oxidized by the B isoform to yield oxaloacetate with reduction of NAD. When temperatures decrease, the metabolic activities are reduced and oxaloacetate would be utilized in hexose synthesis or in transaminations. When temperatures increase, metabolic activity also increases and oxaloacetate would be reduced to malate by the A isoform, yielding NAD, which could be used by glyceraldehyde-3-phosphate dehydrogenase, favoring the glycolytic direction. If in the perciform $G$. brasiliensis the $\mathrm{B} 2$ isoform has arisen via gene duplication it would broaden this metabolic pathway (since it has a lower $\mathrm{Km}$ value and consequently a higher substrate affinity than the B1 isoform) by increasing the efficiency in the malate-aspartate shuttle which would involve the $B *$ locus.

According to our previous paper (Aquino-Silva et al. 1998), the first hypothesis proposed by Monteiro et al. (1991, 1998), viz. a duplication event in progress, better explains the complex electrophoretic pattern detected at $G$. brasiliensis, which would be influenced by genetic drift.

\section{Acknowledgments}

We are grateful to the Genetics and Evolution Department (UFSCar, São Carlos), for technical support, and $\mathrm{CNPq} / \mathrm{CAPES} / \mathrm{FAPESP}$ for the financial support.

\section{References}

Aquino-Silva MR, Schwantes MLB and Schwantes AR (1997) The multiple soluble malate dehydrogenase of Hoplias malabaricus (Characiformes). Exp Biol Online 2:18.

Aquino-Silva MR, Schwantes MLB and Schwantes AR (1998) The multiple soluble malate dehydrogenase of Geophagus brasiliensis (Cichlidae, Perciformes). Genet Mol Biol 21:415-4757.

Aquino-Silva MR, Schwantes MLB and Schwantes AR (2003) Isoform expression in the multiple soluble malate dehydrogenase of Hoplias malabaricus (Erythrinidae, Characiformes). Braz J Biol 63:7-15.

Bailey GJ, Cocks GT and Wilson AC (1969) Gene duplication in fishes: Malate dehydrogenase of salmon and trout. Biochem Biophys Res Comm 34:605-612.

Bailey GS, Wilson AC, Halver JE and Johnson CL (1970) Multiple forms of supernatant malate dehydrogenase in salmonid fishes: Biochemical, immunological and genetic studies. J Biol Chem 245:5927-5940.

Banaszak LT and Bradshaw RA (1975). Malate dehydrogenase. In: Boyer PD (ed). The Enzymes XI. Academic Press, New York, pp 369-396.

Caraciolo MC, Val AL and Almeida-Val VMF (1996) Malate dehydrogenase polymorphism in amazon curimatids (Teleostei, Curimatidae): Evidence of an ancient mutational event. Rev Bras Genet 19:57-64.

Coppes ZL, Schwantes MLB and Schwantes AR (1987) Adaptative features of enzymes from family Scianidae (Perciformes) - I. Studies on soluble malate dehydrogenase (sMDH) and creatine kinase (CK) of fishes from the south coast of Uruguay. Comp Biochem Physiol 88B:203-209.

Davidson RG and Cortner JA (1967) Genetic variant of human erythrocyte malate dehydrogenase. Nature 215:761-762.

De Luca PH, Schwantes MLB and Schwantes AR (1983) Adaptative features of ectothermic enzymes IV. Studies on malate dehydrogenase of Astyanax fasciatus (Characidae) from Lobo Reservoir (São Carlos, São Paulo, Brasil). Comp Biochem Physiol 47B:315-324.

Farias IP and Almeida-Val VMF (1992) Malate dehydrogenase (sMDH) in amazon cichlid fishes: Evolutionary features. Comp Biochem Physiol 103B:939-943.

Fenerich-Verani N, Schwantes MLB and Schwantes AR (1990) Patterns of gene expression during Prochilodus scrofa (Characiformes, Prochilodontidae) embryogenesis - II. Soluble malate dehydrogenase. Comp Biochem Physiol 97B:247-255.

Ferris SD (1984) Tetraploidy and the evolution of the catostomid fishes. In: Turner JB (ed) Evolutionary Genetics of Fishes. Plenum Press, New York, pp. 653.

Ferris SD and Whitt GS (1977) Duplicate gene expression in diploid and tetraploid loaches (Cypriniformes, Cobitidae). Biochem Genet 15:1097-1111.

Ferris SD and Whitt GS (1978) Phylogeny of tetraploid Catastomid fishes based on the loss of duplicate gene expression. Syst Zool 27:189-206.

Ferris SD and Whitt GS (1979) Evolution of the differential regulation of the duplicate genes after polyploidization. J Mol Evol 12:267-317.

Hochachka PW and Somero GN (1984) Biochemical Adaptation. Princeton University Press, Princeton, pp 537.

Kitto GB and Lewis RG (1967) Purification and properties of tuna supernatant and mitochondrial malate dehydrogenase. Biochem Biophys Acta 139:1-15.

Lin JJ and Somero GN (1995a) Temperature-dependent changes in expression of thermostable and thermolabile isozymes of cytosolic malate dehydrogenase in the eurythermal goby fish Gillchthys mirabilis. Physiol Zool 68:114-128. 
Lin JJ and Somero GN (1995b) Thermal adaptation of cytoplasmic malate dehydrogenase of Eastern Pacific barracuda (Sphyraena ssp): The role of differential isoenzyme expression. J Exp Biol 198:551-560.

Lin JJ, Yang TH, Wahlstrand BD, Fields PA and Somero GN (2002) Phylogenetic relationships and biochemical properties of the duplicated cytosolic and mitochondrial isoforms of malate dehydrogenase from a teleost fish, Sphyraena idiastes. J Mol Evol 54:107-17.

Markert CL and Moller F (1959) Multiple forms of enzymes: Tissue, ontogenic and species specific patterns. Proc Natl Acad Sci USA 45:753-763.

McAlister-Henn L (1988) Evolutionary relationships among the malate dehydrogenase. Trends Biochem Sci 13:178-181.

Monteiro MC, Schwantes MLB, Schwantes AR and Aquino-Silva MR (1998) Thermal stability of soluble malate dehydrogenase isozymes of subtropical fish belonging to the orders Characiformes, Siluriformes and Perciformes. Genet Mol Biol 21:191-199.

Monteiro MC, Schwantes MLB and Schwantes AR (1991) Malate dehydrogenase in subtropical fish belonging to the orders Characiformes, Siluriformes and Perciformes. I. Duplicate gene expression and polymorphism. Comp Biochem Physiol 100B:381-390.

Schwantes MLB and Schwantes AR (1977) Eletrophoretic studies on polyploid amphibians. III. Lack of locus duplication evidences through tetraploidization. Comp Biochem Physiol 57B:341-351.

Schwantes MLB and Schwantes AR (1982a). Adaptative features of ectothermic enzymes. I. Temperature effects on the malate dehydrogenase from a temperate fish, Leiostomus xanthurus. Comp Biochem Physiol 72B:49-58.

Schwantes MLB and Schwantes AR (1982b) Adaptative features of ectothermic enzymes. II. The effects of acclimation temperature on the malate dehydrogenase of the spot, Leiostomus xanthurus. Comp Biochem Physiol 72B:59-64.

Shaklee JB, Allendorf FW, Morizot DCF and Whitt GS (1989) Genetic nomenclature of protein - Coding loci in fish: Proposed guildelines. Transac Amer Fish Soc 118:218-227.

Val AL, Schwantes AR, Schwantes MLB and De Luca PH (1981) Amido hidrolisado de milho como suporte eletroforético. Ciênc Cult 33:992-996.

Whitt GS (1970) Genetic variation of supernatant and mitochondrial malate dehydrogenase isozymes in the teleost Fundulus heteroclitus. Experientia 26:734-736.

Associate Editor: Antônio Sole-Cava

License information: This is an open-access article distributed under the terms of the Creative Commons Attribution License, which permits unrestricted use, distribution, and reproduction in any medium, provided the original work is properly cited. 